UDC 656.7.025

DOI https://doi.org/10.32838/2663-5941/2021.2-2/25

Volkovska G.G.

orcid.org/0000-0001-9674-3770

National Aviation University

Akmaldinova V.Ye.

orcid.org/0000-0002-7087-2088

National Aviation University

\title{
METHODICAL PRINCIPLES OF FORECASTING AIR CARGO FLOWS
}

Most of the planning transport systems tasks have become operational, they are solved on the basis of large amounts of available information. The use of traditional methods, including transport tasks, has also changed significantly. In practice, transport companies are not subject to the freight flows formation, so they accept ready-made information about them. The amount of initial data for each specific carrier is a random variable. Parameters of their distribution depend on period to which information relates. Based on it, transport companies distribute rolling stock to known orders. In each case, using its expected characteristics, they need a differentiated approach to assessing production situation. Usually, there is such method of evaluation. Carrier predicts future transport tasks with accuracy that satisfies its ability to quickly situation change, and then plans routes and distributes existing fleet to them.

Air cargo forecasting is characterized by significant complexity due to extensive airlines network, presence of a large clientele, small consignments and other factors that are difficult to forecast (e.g., one-time shipments). Therefore at cargo transportations forecasting the statistical methods based on transportations dynamics analysis for a number of years, studying of factors defining growth rates, account of perspective directions to air transport development and economy of serviced gravity areas. At deep enough analysis of transportations dynamics and revealing of steady tendencies it is possible to use extrapolation methods with subsequent correction of results on possible transportations conditions change. For example, when changing preferential conditions of transportation, forecast results should be adjusted. It is also necessary to take into account changes in airlines structure, cargo flows, aircraft-helicopter fleet, etc. Since extrapolation results are influenced by past trends, forecast should focus on analyzing and taking into account factors that determine transportations volume in order to exclude unusual deviations and identify stable trends that will persist in future.

Therefore, the article investigates principles of forecasting cargo flows for airlines. Main methods and models of forecasting are considered. Their advantages and disadvantages are identified.

Key words: forecasting, cargo flow, air transportation, transportation volumes, model of forecasting.

Formulation of the problem. Implementation of effective cargo flow management for the network air carrier is impossible without high-quality air cargo flows forecasting. In the conditions of dynamic external competitive environment change, fluctuations of demand in target markets, considerable internal risks for carrier, creation of universal forecasting bases for air cargo flows is simply vital.

Analysis of recent research and publications. Problems of cargo flow management have been widely studied by Ukrainian leading scientists and foreign countries. Main scientific researches concern cargo flows management at multimodal transportations, researches of forecasting methods applied at passengers and cargoes transportation on international transport corridors, etc. Thus, in the work of P.G. Tregubova [6], based on theory of managed networks and queuing networks, developed number of cargo flow management models, aimed at solving optimization problems of multimodal transportation system. In the work of A.A. Zenkin [3] made an analysis of forecasting methods used in passengers and goods transportation on international transport corridors. It is noted that when forecasting freight transportations volume can be used known methods of regression analysis, where total transportation volume is determined depending on forecast volumes of exports and imports in value terms, as well as on the basis of time series analysis of accepted goods range. Researchers did not ignore problems of transportation management in air transport. In particular, in the work of V.Yu. Ivannikova, P.O. Yanovsky, S.Yu. Girich [4] when determining volumes of different cargo categories in airport cargo flow, it is proposed to use discrete 
function values of posteriori probability distribution of these volumes from the moments of receipt for each observation year. A. Koren's article [5] considers two forecasting models: forecasting volume of air transportations on airlines taking into account macroeconomic indicators of the region and forecasting volume of air transportations on airlines taking into account macroeconomic indicators of the region and other similar airports. Regression analysis method is used to predict passenger air transportation. As accompanying variables (factors) are used: data on demand for air transportation, gross regional product, index of average tariff of transportation and average per capita population income, growth rate of indicators. Second model introduces additional variables, in particular taking into account number of people served by airport who live in area covered by airport.

As noted earlier, V.S. Wojciechowski, T.Yu. Gabrielova and M.Yu. Grigorak in [2] forecasting is based on market analysis and historical indicators of cargo flows. Forecasting itself is one of the block diagram initial components of phased management of network carrier's flight loading. Authors continue scientific research and define principles of forecasting cargo flows on airline network.

Formulation of article goals. The main article goal is to substantiate methods and models of forecasting cargo flows in air connection delivery.

Presenting main material. Volumes and directions substantiation of cargo transportations is carried out at all stages of forecasting: perspective, current (annual), operative.

As noted L.A. Yaschenko in [1], when forecasting cargo transportations on individual airlines, data on transportation of each correspondence for a number of years are studied and summarized. Forecast of cargo shipments from airport can be obtained as the sum of projected shipments by individual airlines. However, study of airline transportations dynamics does not always reveal stable trends in the context of each individual correspondence. Therefore, group or general models are used to forecast transportations volume from the airport as a whole, distinguishing between primary, transfer (regular) and charter transportations. In this case, total amount of cargo shipments from airport

$$
\sum W_{c}=W_{p r}+W_{t r}+W_{c h}
$$

where $W_{p r}$-volume of primary shipments; $W_{t r}-$ volume of transfer shipments; $W_{c h}$ - volume of charter shipments.

For air cargo transportations are characterized by the fact that most of them are performed on passenger aircraft in reloading order. Knowing ratio of passen- ger and cargo load and prospective passenger shipments volume, you can forecast cargo shipments volume for settlement period. This method of forecasting will give more reliable results than extrapolation of time series, as it assumes availability of data on passenger transportations volume.

Calculation of possible cargo shipments from airport, where most of them are performed in passenger fleet, can be done by formula

$$
\sum W_{c}=\sum W_{p} k_{c . p} k_{s t}
$$

where $\sum W_{p}$ - tonnage of shipments in passenger fleet; $k_{c . p}$-coefficient that takes into account ratio of cargo shipments and passenger tonnage; $k_{s t}$ - coefficient that takes into account changes in aircraft fleet structure.

Volume of primary cargo shipments

$$
W_{p r}=\gamma_{p r} \sum W_{c}
$$

where $\gamma_{p r}$ - share of primary shipments in total and cargo shipments from airport.

Volume of transfer shipments

$$
W_{t r}=\sum W_{c}\left(1-\gamma_{p r}\right)
$$

Equation can be used to determine cargo shipments volume

$$
\sum W_{c}=a_{0}+a_{1} W_{p}
$$

where $W_{p}$ - tonnage of passenger shipments; $a_{l}$, $a_{2}$ - equation parameters.

Volume of primary and transfer cargo shipments is calculated by their share in total shipments. Ratio between primary and transfer shipments depends on the amount of arrived transfer cargo and carrying capacity of the fleet. At fixed value of carrying capacity, increase in arrival of transfer cargo leads to decrease in primary shipments. Therefore, when forecasting ratio between shipments types, it is necessary to analyze dynamics of arrival of transfer cargo and identify reasons for increase or decrease of this indicator.

If cargo transportations are carried out on passenger and freight fleets, then

$$
\sum W_{c}=W_{p . s h}+W_{c . s h}
$$

where $W_{p . s h}, W_{c . s h}$ - volume of shipments in passenger and freight fleets.

$$
\begin{gathered}
\sum W_{c}=\sum N_{p . s h} G_{p r . p}+\sum N_{c . s h} G_{p r . c}+ \\
+\sum N_{p . s h} G_{t r . p}+\sum N_{c . s h} G_{t r . c}
\end{gathered}
$$

where $N_{p . s h}, N_{c . s h}$ - air flights of passenger and cargo aircraft; $G_{p r . p}, G_{p r . c}$ - average loading of passenger and cargo aircrafts with primary cargoes; $G_{t r . p}$, 
$G_{t r . c}$ - average loading of passenger and cargo aircrafts by transfer cargoes.

All forecasting methods, which are based on reported data, have one common disadvantage: they do not allow identifying the real demand for air cargo transportations.

To establish the needs of air transportation, it is necessary to analyze dynamics of presenting cargo by stable clientele and to conduct research on new shippers. Possible volumes of transportations can be established by developing transport and economic balances and justifying rational air transportations routes. Since the entire large clientele of air transport can not be covered by balance and route calculations, then choose the largest and most stable companies-senders and cargo flows of some homogeneous cargo (e.g., perishable). The rest of entire clientele can be grouped by departmental basis and forecast can be obtained according to relevant departments. According to clientele, which cannot be covered by justifications, forecast is made by various statistical methods. Model of forecasting cargo shipments by clientele

$$
\sum W_{c}=W_{b}+W_{\text {new }}+W_{\text {another }}+W_{t r}
$$

where $W_{b}$ - volume of shipments by clientele of base period; $W_{\text {new }}$ - volume of shipments for new clientele, identified in the economic research process; $W_{\text {another }}$ - volume of shipments for another clientele; $W_{t r}$ - volume of transfer cargoes shipments.

Taking into account technical and economic features of air transport, scheme of cargo transportations forecasting includes following stages:
- detailed analysis of cargo transportations development by directions and types of shipments (primary and transfer), development method (passenger and cargo fleet), regularity of cargoes arrival (year-round, seasonal), degree of stability (contractual, one-time), cargo types;

- economic research organization of air transporting cargoes in the airports gravity areas and individual airlines;

- development of transport and economic balances for certain cargo types and sending enterprises with justification of rational air transportation directions;

- substantiation of forecasts variants of air transportations volumes and directions with their further estimation;

- working-out proposals for air cargo transportations development.

Structural scheme of economic research and substantiation of cargo transportations volumes and directions is given in figure 1 .

When forecasting cargo flows, main initial information is reporting data on transportation and materials of enterprises (organizations) inspection in order to identify air transporting goods and their delivery routes. To more fully account for air cargo transportations demand, in addition, it is necessary to establish number of unsatisfied applications for cargo delivery by air. Therefore, at airports and agencies should be established accounting of shippers who were denied transportation, indicating reasons for refusal.

Work on attracting cargo for air transport begins with drawing up plan-schedule of enterprises inspec-

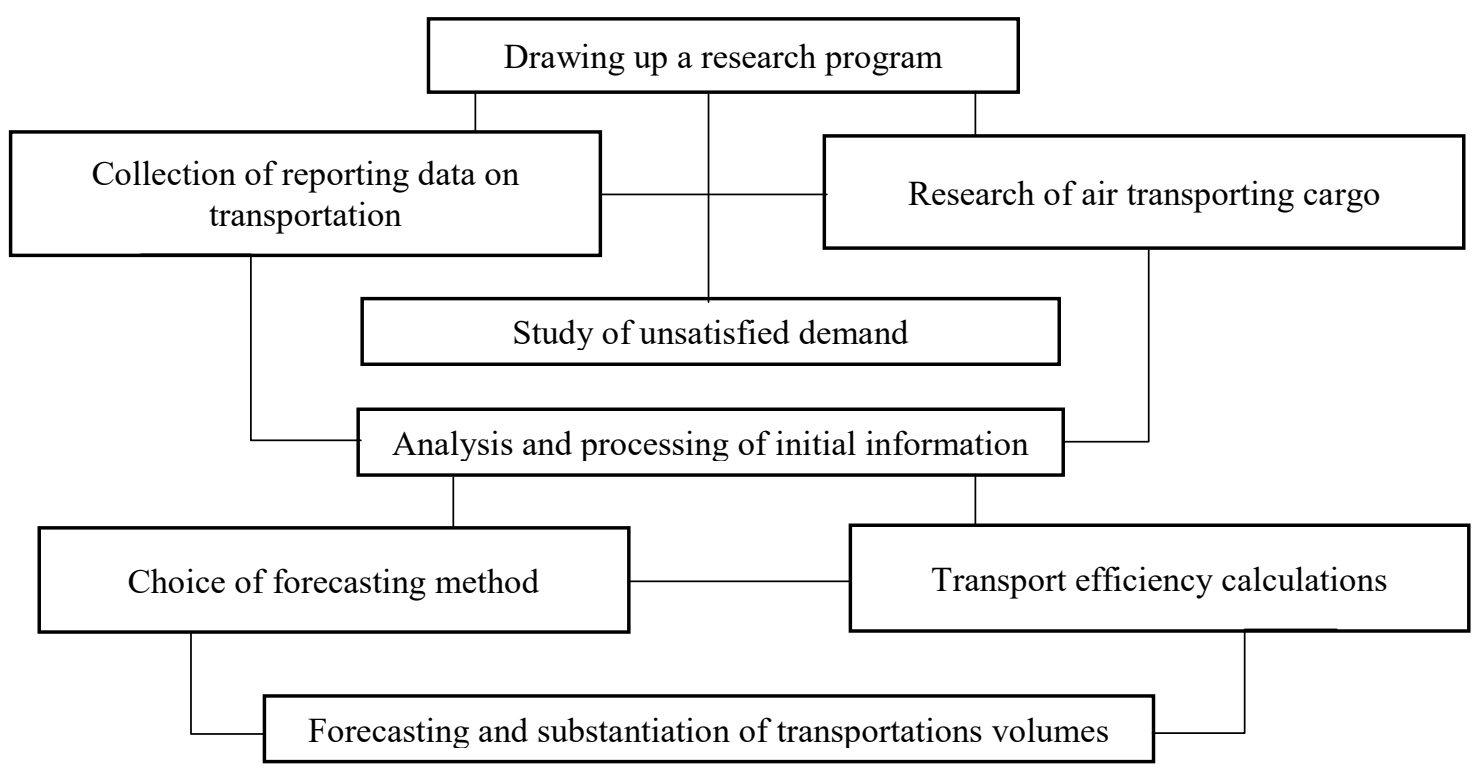

Fig. 1. Scheme of economic research and forecasting of cargo flows 
tion and preparation of working documentation: letters, forms, advertising materials, rules of transportation and tariffs, preferential terms, forms of contracts, etc. Products nomenclature is studied directly at the enterprises, its conformity to air transportation conditions is defined: physical and chemical properties, tare, dimensions and weight of separate places, delivery conditions, etc. Directions and cargo consignment are analyzed, actual transportations by other transport modes are established. Particular attention is paid to the routes of mixed transportation with transshipment on the transportation way. In the process of inspection the terms of production delivery (with involvement of transport organizations data) and data on production losses in transportation process are analyzed.

The survey of enterprises is not limited to local airport gravity area. Transfer cargo flows and consignees are subject to study in order to obtain their consent to air transportation. Analysis and processing of received materials for inspection of enterprises and statistical data on departures and arrival of cargoes with subsequent performance of necessary technical and economic calculations is basis for forecast development of possible air cargo transportations volumes and directions.

On the basis of general theory of economic cycles, researchers [2] have built factor effects table for different types of forecasting (table 1). Thus, long-term forecasting will be characterized by general longterm trends of studied series, which are determined by technological changes, as well as factors that affect economic activity, overall market development and individual carriers. Medium-term forecasting will be dominated by cyclical factors and seasonal changes. In short-term forecasting, decisive role should be given to rapid and adequate response to unpredictable or difficult-to-predict events in long or medium term.

In the long-term forecast, moving average methods, trend estimation, statistical data, vector autoregression should be used. In medium-term forecast, methods of averages, seasonal approach, and concept of Ansoff gaps should be used. At short-term forecast Delphi method, construction of scenarios, forecast by analogy, composite forecasts should be used.
First of all, when forecasting cargo flows on airlines, principles of sliding forecasting should be implemented, which consist in the use of continuous revision of previous plan, as well as principles of flexible forecasting, which take into account possibility of ambiguous conditions and appropriate revision of plan.

Here are examples of forecasting own transportation volumes with general positive, as well as with general negative forecast in market. Let existing airline volume in market - $1000 \mathrm{t} / \mathrm{year}$, total market volume -10000 t/year, i.e. airline owns $10 \%$ of market. With overall positive forecast of market development and growth of its volumes by $10 \%$, the growth of carrier's volumes will be $1000 \times 1.1=1100$ tons. With forecast to increase airline's market share by $2 \%$, we determine that overall growth of airline transportation due to the increase in market share will be $1100 \times 1.2=1320$ tons. It also determines change in airline transportation with negative market forecast, when market falls by $10 \%$, airline's transportation will decrease by $900 \mathrm{~kg} / \mathrm{year}$, but by increasing market share by $2 \%$ airline will be able to compensate for market $1080 \mathrm{t} / \mathrm{year}$.

Nowadays, during the economic downturn, air carriers focused on improving their operational efficiency in an effort to stem losses in a very tough market. Despite all that uncertainty, airlines are lining up to invest in new aircraft. This level of investment suggests that carriers will soon encounter some economic turbulence, as the rate of aircraft delivery is outpacing projections for near-term growth in the airfreight market.

COVID-19 pandemic has affected almost all sectors of economy, but air transport has suffered the most in 2020. However, situation will not improve soon: International Air Transport Association predicts that next year the global aviation industry will suffer multibillion-dollar losses, and will begin to recover no earlier than the end of 2021.

According to results of 2020, volume of cargo transportation and mail by air transport of Ukraine amounted to 88.3 thousand tons (in 2019 - 92.6 thousand tons). Leaders of cargo transportation are ZetA-

Table 1

Factor influence in different forecasting types

\begin{tabular}{|l|l|l|}
\hline \multicolumn{1}{|c|}{ Type of forecast } & \multicolumn{1}{|c|}{ Characteristic } & \multicolumn{1}{|c|}{ Forecasting methods } \\
\hline Long-term & $\begin{array}{l}\text { Long-term trends in technological support, } \\
\text { factors influencing economic activity }\end{array}$ & $\begin{array}{l}\text { Moving average method, trend estimation, } \\
\text { statistical data, vector autoregression }\end{array}$ \\
\hline Medium-term & $\begin{array}{l}\text { Dominance of cyclical factors and seasonal } \\
\text { changes }\end{array}$ & $\begin{array}{l}\text { Method of averages, seasonal approach, } \\
\text { concept of Ansoff gaps }\end{array}$ \\
\hline Short-term & $\begin{array}{l}\text { Significant impact of unpredictable or difficult- } \\
\text { to-predict events in the long or medium term }\end{array}$ & $\begin{array}{l}\text { Delphi method, construction of scenarios, } \\
\text { forecast by analogy, composite forecasts }\end{array}$ \\
\hline
\end{tabular}


via Airlines, Antonov State Enterprise, Maximus Airlines, Ukraine International Airlines, Constanta and Skype. These airlines performed almost 90 percent of the total cargo and mail transportations. It should be noted that most of cargo transportations has traditionally been charter flights to other countries under UN humanitarian and peace programs, as well as under contracts and agreements with other customers.

IATA suggests that only in the fourth quarter of 2021 can we talk about restoring profitability of industry: when aggressive reduction of costs in airlines stops, countries will begin to actively open borders and the flow of cargo will increase significantly.

Ukrainian air industry lost up to 90 traffic during first decade of corona crisis. When air traffic was partially restored, cargo transportations feels much better - their fall was about $20 \%$, and freight traffic partially offset the loss of passenger traffic. It is difficult to predict in what condition Ukrainian aviation will enter next year.
Conclusions. Thus, it was determined that the conditions of dynamic change of external competitive environment, fluctuations in demand in target markets, significant internal risks for carrier to create universal basis for forecasting cargo flows on airlines is simply vital necessity.

It was established that the process of synthesis of quantitative and qualitative forecasting methods should be carried out by implementing universal algorithms and schemes for forecasting cargo flows.

Basic methods and models of air transportation volumes are substantiated. On the basis of general theory of economic cycles table of factor influence at various forecasting types is resulted. General scheme of economic researches and forecasting of cargo flows is realized. As an illustration, examples of forecasting of own transportations volumes at general positive and negative forecasts in market, and also statistical data on situation in Ukrainian cargo air transportations market are resulted.

\section{References:}

1. Ященко Л.А., Шаповал Н.С., Мержвінська А.Н. Техніко-економічні вишукування та прогнозування розвитку галузі: навч. посібник. Київ: Центр учбової літератури, 2006. 240 с.

2. Войцеховський В.С. Реалізація системи управління завантаженням мережевим авіаперевізником. Вісник Східноукраӥнського національного університету ім. Володимира Даля. 2017. Вип. 4(234). С. 69-75.

3. Зенкин А.А. Методы прогнозирования перевозок по международным коридорам. Соискатель приложение к журналу «Мир транспорта». 2015. Вип. 1(9). С. 68-72.

4. Иванникова В.Ю. Моделирование объемов грузовых перевозок в аэропорту : матеріали міжн. наук.практ. інтернет-конф. «Комп'ютерні технології в міському та регіональному господарстві», м. Харків, 23-28 листопада 2015 p. Харків, 2015. URL: http://ojs.kname.edu.ua/index.php/area/article/view/534.

5. Корень А. Стратегический подход к развитию региональных авиаперевозок. URL: https://www.aex. $\mathrm{ru} / \mathrm{docs} / 8 / 2013 / 10 / 3 / 1891$.

6. Трегубов П.Г. Повышение эффективности управления системой ускоренных мультимодальных перевозок путем моделирования грузопотоков на основе управляемых сетей : автореф. дисс. ... канд. техн. Наук : 05.22.01. Москва, 2015. 23 с.

\section{Волковська Г.Г., Акмалдінова В.Є. МЕТОДОЛОГІЧНІ ПРИНЦИПИ ПРОГНОЗУВАННЯ АВІАЦІЙНИХ ВАНТАЖОПОТОКІВ}

Більшість завдань планування транспортних систем набули оперативного характеру, вони розв'язуються на основі великої кількості доступної інформації. Застосування традиційних методів, зокрема транспортних завдань, також суттєво змінилося. На практиці транспортні компанї не є суб'єктами формування вантажних потоків, тому приймають готову інформачію про них. Кількість вихідних даних для кожного конкретного перевізника є випадковою величиною. Параметри їх розподілу залежать від періоду, до якого належсить інформація. На його основі транспортні компанії розподіляють рухомий склад за відомими замовленнями. У кожному випадку, використовуючи очікувані характеристики, їм потрібно диференційовано підходити до оцінки виробничої ситуачії. Зазвичай є такий метод оцінки. Перевізник передбачає майбутні транспортні завдання з точністю, яка задовольняє його здатність швидко змінювати ситуачію, а потім планує маршрути та розподіляе наявний парк.

Прогнозування вантажних авіаперевезень вирізняється значною складністю, зумовленою розгалуженою мережею авіаліній, наявністю численної клієнтури, дрібними партіями відправок та іншими факторами, які важко піддаються прогнозуванню (наприклад, разові відправки). Тому під час прогнозування вантажних перевезень знаходять застосування статистичні методи, основані на аналізі динаміки перевезень за низку років, вивченні факторів, щзо визначають темпи зростання, обліку перспективних напрямів розвитку повітряного транспорту й економіки обслуговуваних районів 
тяжіння. За досить глибокого аналізу динаміки перевезень $і$ виявлення стійких тенденцій можна використовувати методи екстраполяиії з подальшою корекцією результатів на можливу зміну умов перевезень. Наприклад, під час змінипільговихумовперевезеньвартоскоректувати результати прогнозу. Необхідно також враховувати зміни в структурі авіаліній, вантажопотоків, літако-вертолітного парку та ін. Оскільки на отримані екстраполяцією результати впливають минулі тенденції, то основну увагу під час прогнозування повинно бути приділено аналізу та врахуванню факторів, що визначають обсяги перевезень із метою вилучення нехарактерних відхилень і встановлення стійких тендениій, які зберігатимуться в майбутньому.

Тому стаття досліджує принципи прогнозування вантажсопотоків для авіаліній. Розглянуто основні методи та моделі прогнозування. Визначено їхні переваги та хиби.

Ключові слова: прогнозування, вантажопотік, авіачійні перевезення, обсяги перевезень, модель прогнозування. 